\title{
THREE QUESTIONS ON AUTONOMY AND LABOUR THEORY OF VALUE
}

\author{
JAN SOWA
}

I'd like to bring forward three issues, which are somehow connected, but also distinct. I will formulate them in a way that is similar to the doubts and arguments I often face in public discussions when I refer to (post)operaism in a hope to confront our opponents. So it's an "internal party critique" and not an attack from the outside.

The first one deals with the questions of the autonomy of living labor and its real subsumption to capital. Post-operaist thinkers, Hardt and Negri included, like to underline the growing autonomy of labor and its ability to organize the production process without any intervention from capital; or, even, an ability to do it better than capital itself. Hence the conviction that the boss is much more an obstacle than an organizing agent -- or the idea of exodus, understood as an ability of living labor to completely leave, with its productive capabilities, the sphere of capitalist production. At the same time, the same thinkers seem very much influenced by Karl Marx's idea of the real subsumption of the living labor under capital, a situation of broader and much more widespread control of capital over the entire productive process -- as compared with a merely formal subsumption characteristic of the former phases of capitalist development (in the form of the "social factory" to use Mario Tronti's expression, the ongoing precarization of labor relations, the biopolitical nature of production under the flexible regime of postfordist accumulation, the further division of productive process into smaller time-units that are more easily manageable as claimed by Franco "Bifo" Berrardi etc.). 
These two diagnoses seem deeply contradictory - how can stronger subsumption (and the real one seems stronger than the formal one due to its deeper and vaster penetration of the production process) can be combined with broader autonomy?

The second issue deals also with the notion of autonomy and concentrates on the classical operaist theses of the primacy of struggles in shaping capitalist economy. I very much appreciate the accounts given by Negri of Keynes reading Lenin and advising how to reform capitalism in order to avoid a revolution in the West. I have no doubts that struggles play an important role in transforming the capitalist organization of production and the social relations surrounding them. I just don't see any evidence for the thesis of the primacy of struggles and the fundamental role they play. The basic force animating capitalism seems to be an utterly irrational (in a material as opposed to formal sense) urge to accumulate capital. How does it stem from struggles? Are struggles in any way its cause? Can it be explained by struggles? This seems very problematic. The struggles themselves rather seem to be a reaction to this accumulation urge and an attempt to stop it from completely destroying society. An equally strong role in the transformation of capitalism can be ascribed to, for example, technological innovation. Sometimes, not always, it comes as a reaction to struggles. But it's often motivated by the above-mentioned urge to accumulate more capital thanks to, for example, the extension of the geographical base for capitalist operation (through, for instance, time-space compression as noted by David Harvey). Contemporary delocalization of production is provoked to an important extend by rising costs of labor force in the core of capitalist system as a result of social struggles, however the early expansion of capitalist commerce in the colonial system does not seem to be related to them in any fundamental way, especially because it happened before waged labor had become sufficiently widespread to be able to organize and fight against exploitation. (It can be even argued that the very development of system of wage labor stemmed from an early accumulation of capital and productive resources achieved via the colonial expansion of 16 th century). There were other factors that were also not related at all to struggles. The Ottoman blockade of the ground trade route to China played a bigger role in geographical 'discoveries' - which were necessary for capitalist development, as they lay the groundwork for the creation of the world market - than any social struggle in $15^{\text {th }}$ century Europe.

The third issue is the most abstract one and focuses on the supposed crisis of labor theory of value. This crisis is often denounced in postoperaismo with a reference to the famous "Fragment on Machines" from Grundrisse, where Marx himself puts the labor theory into question. However Marx very clearly and explicitly refers to the world of future communism, where not the labor time, but "disposable time", as he puts it, will serve as a measure of value. It seems that as long as we live within capitalism (and there is no vanguard outside it) and we want to analyze from a Marxist - and not, for instance, neoclassical - economic perspective, 
we will remain under the hold of the labor theory of value. Is there any other solution to this problem than the idea of "ontological communism" (the notion of the new order being born in the shell of the old one) that was so sharply debated between Negri and Alain Badiou/Slavoj Žižek during both the London and Berlin "On the idea of Communism" conferences? And how, in practice is this "ontological communism" to be understood? Does this "ontological communism" exist in the most advanced sectors of capitalist production (products and services based on digital technologies and telecommunication, biotech etc.) or somewhere else? As far as labor conditions are concerned, these sectors are rather an avant-guard of precarization, flexibilization, new forms of exploitation, new forms of enclosures of the commons (like genes), etc. It is difficult to see there any glimpse of a better, future world. 
Jan Sowa - is an independent researcher, sociologist, writer and activist. He studied literature, philosophy and psychology at the Jagiellonian University, Kraków and University Paris 8 in Saint-Denis. He holds a Ph.D. degree in sociology and habilitation degree in cultural studies. In his research Sowa explores the border of cultural studies, social anthropology, critical theory, art and politics. He wrote and edited several books on art, society, media, history as wells as social and political theory (most recently: Inna Rzueczpospolita jest możliwa! Widma pržesz̧ łości, wizj]e prayszłości, Warszawa 2015). He published around 100 texts both in Poland and abroad.

EMAIL: jan.sowa@ha.art.pl

CITATION: Sowa, Jan. 2015. "Three questions on autonomy and labour theory of value." Praktyka Teoretyczna 2(16): 151-154

DOI: 10.14746/prt.2015.2.7

AUTOR: Jan Sowa

TYTUL: Trzy pytania o autonomię i teorię wartości opartej na pracy 